\title{
Democratizing Democracy? \\ Civil Society and Party Organization in Bolivia*
}

\begin{abstract}
Santiago Anria
Abstract: The rise to power of movement-based parties is a new and expanding phenomenon. Existing theories predict these parties will become increasingly oligarchic as they govern nationally. The Bolivian MAS deviates from this conventional wisdom, as it has followed a remarkably different organizational trajectory that has facilitated grassroots impact and constrained elite control. Through a within-case comparative examination of MAS, this paper identifies necessary conditions and explains mechanisms facilitating this outcome in the crucial area of candidate selection. Key to understanding how these parties operate is the organizational context in which they are embedded. Where civil society is strong, has mechanisms to arrive at decisions, and can agree on candidate selection, it can play an important role in resisting the oligarchization of allied movement-based parties.
\end{abstract}

* Forthcoming in Comparative Politics, July 2016 
Political parties have undergone deep changes in recent years. As mass partisanship has increasingly become a relic of the past, parties founded to sustain support for a single charismatic leader have become common - prominent examples include the United Socialist Party of Venezuela under Chávez, and the Italian Forza Italia under Berlusconi. In these parties, the locus of organizational power is squarely at the top. By contrast, other newer parties, like the Green "movement parties" in Europe, reject personalism in the interest of boosting participation and resisting oligarchic pressures. However, success in achieving and maintaining internal grassroots participation, particularly after assuming national power, has generally proven to be elusive. ${ }^{1}$

New parties have been particularly important in Latin America. ${ }^{2}$ One of the most salient developments in the region is the emergence and access to power of left parties representing the interests of the politically and socially marginalized. ${ }^{3}$ Usually described as movement-based parties (MBPs), ${ }^{4}$ they draw their organizational strength from connections to grassroots social movements, like the Brazilian PT (Workers' Party), the Uruguayan FA (Broad Front), and the Bolivian MAS (Movement Toward Socialism). MBPs are not just a Latin American phenomenon; they are also emerging in Africa, the Middle East, Western Europe, Eastern Europe, and North America. ${ }^{5}$ Despite their increasing importance, we know little about how these parties work. Research has tended to focus on the origins of MBPs, ${ }^{6}$ but their internal politics remain both under-examined and under-theorized.

In Latin America, the ascension of MBPs to national-level power generated some optimism about the prospects for building internally democratic organizations that encourage wide and substantive participation of organized civil society in decision-making. Extending direct grassroots participation, which has been associated with the post-Cold War notion of 
"deepening" democracy, is a historic goal of the left in Latin America. ${ }^{7}$ Scholars have shown that new left parties and political movements in power in Latin America vary in the extent to which their internal structures disperse authority, ${ }^{8}$ but a fundamental question still remains unanswered: What are the sources of variation between and within parties?

This question has a long lineage. It goes as far back as Michels's oligarchy theory, which, in its short version, predicts the inevitable rise of elite-dominated hierarchical structures that concentrate power and de-emphasize bottom-up participation in procedures of social choice. ${ }^{9}$ Michels's theory is the argument influential analyses of party organization either explicitly confront or confirm. ${ }^{10}$ Framed as a "fundamental sociological law of political parties," it denies the very possibility of democratic modes of governance within parties - particularly as they contest elections and access power. The idea of internal party democracy has regained attention in the comparative study of political parties, partly in response to the almost-universal crises of representation and the decline of mass party membership. ${ }^{11}$ But, under what conditions can parties escape a seemingly inevitable oligarchic fate?

This question is important for substantive and theoretical reasons. Substantively, parties are crucial for democracy; they are key for political interest aggregation and the translation of programs into policies. Their internal structures have implications not only for inter-party competition, but also for shaping public policy outcomes. For example, more internally democratic parties generally push policy in a more redistributive and universalistic direction. ${ }^{12}$ Thus, there is a potentially high payoff for research on the sources of variation in the internal distribution of power within and between parties.

Theoretically, understanding the internal life of an increasingly common phenomenon like MBPs adds to one of the most strikingly under-developed literatures in comparative politics: 
the debate about what happens inside the "black box" of parties. ${ }^{13}$ Even though parties remain weakly organized in much of the developing world, the era of party building is far from over and MBPs are well equipped to build strong organizations. ${ }^{14}$ We need to understand how they work.

Current research focuses mostly on the conditions giving rise to strong parties. ${ }^{15}$ The question of whether and how parties can defy oligarchization has received less attention. When democracy within parties is deficient, particularly when these are in power, the voices of citizens may not be heard. When governing parties are democratically organized, by contrast, they may generate opportunities for the empowerment of traditionally marginal groups and individuals. ${ }^{16}$ Arguments about party democracy are arguments about "democratizing" democracy. The goal here is to explain with original, systematic evidence the conditions and mechanisms under which broader and more substantive grassroots participation might be promoted in contemporary governing parties. $^{17}$

This article uses a within-case research design for theory-building purposes. Specifically, it explains variation in patterns of legislative candidate selection within the case of the Bolivian MAS. The value of this approach is twofold. First, the selection of candidates is a central aspect of internal party democracy; its examination reveals critically important information about how parties are organized and how power is allocated within them. ${ }^{18}$ The selection of legislative candidates is the best point from which to study power struggles within parties because they generally involve a broader set of actors and processes than, say, executive elections. ${ }^{19}$ To develop a fuller measure of levels of grassroots influence, elsewhere I examine the degree to which greater grassroots control over the selection of candidates also translates into greater substantive input over party policy. I find that the stronger and most influential organizations that 
wield power over candidate selection are also important in the policy-making realm, but this varies by policy area. ${ }^{20}$

Second, MAS is one of the most successful new MBPs in power in Latin America, and yet the case deviates from the conventional wisdom on this type of party: defying theoretical expectations, it has followed an organizational trajectory that has facilitated grassroots impact and constrained elite control, even after assuming power at the national level. ${ }^{21}$ Conventional accounts of these parties focus on cases that develop a strong organizational infrastructure of collective action before assuming national power, such as the Brazilian PT. ${ }^{22}$ Consequently, their conclusions tend to emphasize the "normalization" of these parties, and the difficulties of sustaining bottom-up participation when they govern at the national level. ${ }^{23}$ As a deviant case, studying MAS serves to advance theory by identifying the conditions in its structure that work against oligarchy, and explaining the mechanisms that make internal responses to the grassroots possible. ${ }^{24}$ The scope conditions of this study are restricted to MBPs that (a) assume power rapidly and that (b) operate in weakly institutionalized contexts.

Concretely, this article identifies necessary conditions and mechanisms that provide opportunities for broad participation and substantive grassroots impact on candidate selection procedures: namely, the presence of strong grassroots organizations that can agree on selection. When such organizations are either absent or unable to agree on selection, elite decision-making is more likely to occur. Thus, I argue, where civil society is strong and united it can play an important role in affecting internal party governance and help impede the oligarchization of allied parties.

This article contributes new theory and empirical findings to debates among scholars of party organization in Latin America and beyond. The literature on parties is dominated by 
Downsian, rational choice approaches that see parties as unitary actors detached from their social bases. ${ }^{25}$ However, sociological and comparative historical approaches have shown that parties are not unitary actors dominated by a unified leadership. ${ }^{26}$ I present new data demonstrating that just as parties operate differently in different localities in how they organize their electoral appeals to different social bases, ${ }^{27}$ they also work differently in the realm of candidate selection depending on the structuring of the political space in which they operate. Although there is a significant amount of new literature on party electoral strategy, ${ }^{28}$ scholars have largely overlooked the critical question of how party-civil society relations shape parties and their internal politics. I show that these relationships vary across geographical constituencies, and that this has meaningful impact on party politics.

\section{MOVEMENT-BASED PARTIES: EXPLAINING THEIR INTERNAL POLITICS}

Institutional and structural factors interact to shape candidate selection. Institutional elements include aspects of a country's electoral system and elements related to the strength of the local party apparatus. Structural factors correspond to the organizational strength of civil society. Strongly organized societies, as the empirical literature shows, serve as a potential power base for parties. They can play not only an important party-building role, but can also shape internal party governance.

\section{Movement-Based Parties (MBPs)}

MBPs are parties with a core constituency of grassroots social movements. This definition parallels Levitsky's definition of labor-based parties, with social movements rather than labor as the core constituency. ${ }^{29} \mathrm{MBPs}$ are also different from Kitschelt's analytical 
characterization of "movement parties," which are almost always electoral vehicles for a social movement mobilized around a single issue. ${ }^{30}$ By contrast, movement-based parties are broader alliances of various movements and, as such, they are better prepared to incorporate a broader set of issues, actors, and demands.

MBPs follow the "organic" model of party development, in that they are organizationally hybrid: they engage in extra-institutional social mobilization, and at the same time compete for office. Members and leaders who run for electoral office tend to be "drawn directly from social movements rather than from the ranks of a separate, professional political caste." ${ }^{31}$ While these parties vary in terms of ideology, ${ }^{32}$ they almost always share a rejection of hierarchical control as well as an explicit commitment to maximizing democratic participation at the grassroots.

MBPs are often seen as "transitional phenomena,",33 but the "into what" question is not settled. One salient argument suggests that the more participatory, "bottom-up" decision-making patterns that are generally present early in the life of an MBP are only viable for a short time. However, MBPs may not evolve in a unilinear way. It is also theoretically plausible that such parties follow contingent structural and strategic incentives that allow for a return to organizational patterns common in early phases. In short, there are no a priori reasons that parties based on movements will transition to a form of party that is hierarchical, exclusive, and centralized. Their genesis in grassroots mobilization and their hybrid nature may encourage democratic control from below. The realization of this potential depends on the organizational strength and unity of allied movements. 


\section{Institutional Elements}

My analysis focuses on two institutional elements - electoral rules and the nature of the local party organization. Electoral systems affect candidate selection by creating space for civil society actors to shape the process. ${ }^{34}$ Mixed-member proportional electoral systems (MMPs), like the one used in Bolivia, force parties to produce individual district candidates alongside a party list. As the literature shows, party leadership tends to become more central to selection and candidate list placement as district magnitude increases. ${ }^{35}$ Thus, it is likely that grassroots organizations will be able to exert more influence on selection for single-member district candidates than for proportional representation candidates.

MMPs create distinct incentives for the party's top leadership, predisposing it toward the selection of different types of candidates. In single-member districts, the key for electoral success is the candidate's personal reputation and support within the district, which leads to three possible scenarios. First, a candidate that emerges with strong backing from grassroots organizations can be accepted by the leadership to increase the probability of getting out the vote. Second, if there are strong organizations but contested nominations, the leadership can provide arbitration to maximize the chance of electoral success. In these cases, the leadership can maximize success by choosing a candidate who is most acceptable to a majority of local organizations. Third, where there are few social organizations linked to the party or where these are weakly organized, the central leadership can use nominations to build alliances with existing organizations or to attract the support of specific social sectors. However, for proportional representation candidates the key to electoral success is the overall strength of the party ticket. Parties often use these candidacies to diversify their lists and attract maximum electoral support. 
Recent studies also highlight the relevance of the organizational strength of party subunits for party outcomes. ${ }^{36}$ In addition to mobilizing supporters and delivering votes, a strong local party organization can play a role in the aggregation of political interests, such as in the selection of candidates. It can either nominate candidates directly, or serve as an arena for resolving conflicts among competing groups. However, variance in the organizational strength of party subunits does not fully explain variation in candidate selection patterns. This article shows that a party's top leadership can serve as an arbiter in chief in conflicts where the local party organization is either weak or strong, but the leadership more likely performs this role in contexts with a strong and heterogeneous civil society that is not fully aligned with the party. In other words, it is the failure of coordination among grassroots actors that, in general, creates an organizational opportunity for the party leadership to centralize power. This finding points to the importance of examining broader structural elements associated with the strength of civil society, and more broadly, with the organizational contexts in which parties are embedded.

\section{Structural Elements}

Structural factors associated with the strength of civil society are central to my explanation. Classic works in political sociology, as well as more recent empirical research on party building, have established that densely organized civil societies can serve as a potential power base for parties. ${ }^{37}$ The expectation is that the organizational infrastructures of politically oriented associations may contribute to building strong parties by reducing costs and coordination problems. This "organizational inheritance" - as Levitsky, Loxton, and Van Dyck argue - can provide invaluable resources to new political parties and contribute to their longterm empowerment. New parties are more likely to take root, and also to persist over time, where 
politicians build upon the infrastructure of pre-existing organizations. MBPs, even if initially loosely organized, are well positioned to build strong parties.

Following these insights, a significant factor affecting the internal governance of parties and their tendencies toward oligarchization is the variation in the organizational strength of their civil society allies. Specifically, I argue that the presence of civil societies that are both (1) strongly organized and (2) united, can generate politically consequential pressures from below. ${ }^{38}$ Strongly organized civil societies are those with high organizational density (percentage of the district's population that are members of grassroots organizations). United means affinity of purpose - the ability to privilege common purpose over narrow organizational interests in order to agree on decisions affecting common interests.

At least four combinations of party-civil society are possible: (1) strong civil society aligned with the party, (2) strong civil society aligned with opposition parties, (3) strong civil society with different political alignments, and (4) weak civil society (in which case political alignments are less relevant). ${ }^{39}$

Systematic evidence from candidate selection within a movement-based party demonstrates that oligarchic decision-making by the party leadership is less likely to take place in districts where grassroots organizations aligned with the party are strongly organized, have mechanisms to arrive at decisions, and can agree on selection. In turn, in contexts where strong grassroots organizations aligned with the party are absent, or where they are strong but have multiple alignments and do not agree on selection, oligarchic decision-making in the hands of a small party elite is much more likely to occur. Similarly, contexts of weak civil society create organizational opportunities for power concentration in the hands of a few. Thus, the evidence highlights the importance of both the strength of civil society organizations and political 
alignments of civil society on candidate selection outcomes. These findings are consistent with recent developments in the social movement literature inspired by the organizational ecology tradition. $^{40}$

Though not yet connected to the literature on political parties, organizational ecologists emphasize the broader organizational field in which parties operate. ${ }^{41}$ Similarly, the findings from the Bolivia case suggest that a potentially rewarding area for further research on the internal dynamics of political parties is the relevant contextual conditions, such as the impact of diverging patterns of party-civil society relations. Just as parties deploy different linkage strategies to attract different electoral constituencies in unequal societies, ${ }^{42}$ their local operations vary according to the way political space is structured.

\section{RESEARCH DESIGN}

MAS is a particularly relevant case for studying MBPs because it deviates from the conventional wisdom. ${ }^{43}$ Although there are observable tendencies towards power concentration, grassroots groups have retained considerable "bottom up" influence in processes of candidate selection in districts where civil society is strong, has mechanisms to arrive at decisions, and can agree on selection. ${ }^{44}$ The result has been salient variation in candidate selection outcomes across different geographical constituencies.

Existing empirical studies offer important insights on how MAS selects candidates;

however, they are generally descriptive and leave critical questions unanswered. ${ }^{45}$ Specifically, although they acknowledge variation within MAS and provide a wealth of qualitative information, they fail to explain what the main sources of that variation actually are. 
My empirical analysis addresses this issue. It examines subnational variation in the selection of candidates for national office in the electoral process leading to the 2009 election. This is a key moment because MAS was in its most expansive phase, and as a result, the lead up to that election can be conceived of as a likely scenario for high degrees of power concentration. I rely on evidence collected through interviews with over fifty MAS representatives from the

districts of La Paz, Cochabamba, Oruro, and Santa Cruz (see Table 1), ${ }^{46}$ in addition to 120 interviews with key informants. Interviewees included leaders of allied grassroots organizations, non-elected regional party brokers, unsuccessful aspirants, members of the executive branch, representatives of opposition parties, experts, journalists, as well as candidates nominated for local office in rural and urban districts. ${ }^{47}$ Data from these interviews are supplemented by a close reading of newspapers on the process and its aftermath, and of the existing secondary literature.

\section{[TABLE 1]}

My analysis reveals tremendous variation across different localities. Conditions where organizations allied to MAS have a near monopoly of organization are more likely to be observed in the rural areas in Bolivia's western departments, including La Paz, Cochabamba, and Oruro, where single-member district candidates are more likely to emerge from social organizations and be accepted by the party leadership. This pattern of candidate selection reflects a de facto diffusion of power, in that it mirrors the balance of power between MAS and territorially grounded grassroots organizations, and also between these organizations themselves.

Bolivia is no exception to the rule that urban areas are generally more heterogeneous than rural areas. In some cities or urban districts the diffusion of power among organizations leads to 
a situation where agreement on candidates is difficult, while in other cases the organizational density (i.e. the presence and strength of organizations aligned with MAS) is significantly lower. In both types of situations, the candidate selection process exhibits a combination of oligarchic decision-making with grassroots participation and consensus building. Specifically, where there are strong organizations but no consensus among them, the leadership is likely to choose a candidate acceptable to a majority of local organizations; where organizations are weak, however, the leadership is likely to select candidates that will help to build alliances with existing organizations or to attract support from particular groups that may increase electoral returns. These patterns are similar to that observed for most proportional representation candidates. Finally, in Bolivia's eastern departments, which represent new arenas of competition for MAS, the social organizations linked to the party are weak. In the absence of strong organizations that can agree on candidate selection, elite decision-making is more likely to occur. $^{48}$

\section{EMPIRICAL SETTING}

Bolivia's bicameral Congress consists of a Chamber of Senators with 36 seats, and a Chamber of Deputies with 130 seats. All elected representatives serve five-year terms, and reelection is permitted. Members of the Chamber of Senators are elected through closed-list proportional representation. Deputies are elected by a mixed-member proportional (MMP)

electoral system that has created two different types of seats, "plurinominal" (proportional representation) and "uninominal" (single-member district -- SMD), forcing parties to produce individual district candidates alongside a party list. In addition, the country's 2009 constitution established seven "special" seats for ethnic minorities. Seventy uninominal representatives are 
elected by plurality vote in single-member districts, fifty-three plurinominal representatives are elected in a closed-list proportional representation system, and the seven special representatives are elected by plurality vote in single-member constituencies. ${ }^{49}$

\section{UNINOMINAL CANDIDATES}

Generally, in selecting uninominal candidates, MAS delegates responsibilities and control to the grassroots organizations that are present in a given electoral district. In these cases, then, candidates emerge based on the strength of the social organization they represent. Prior to an election, the MAS National Directorate requests nominations from allied grassroots organizations throughout the country. These organizations are then in charge of conducting screening, pre-selection, and candidate nomination processes, and they do so by electoral district and according to the norms and procedures they themselves deem adequate. In most cases, the MAS leadership respects the decisions by grassroots organizations. ${ }^{50}$

Formal membership in MAS is not a condition for candidacy. Instead, "aspiring candidates need to be approved by the people in their territory." ${ }^{51}$ The only hard-and-fast rule that MAS respects is that each district has to ensure rigorous gender equality: by statute, if the titular candidate for a district is a man, the substitute needs to be a woman and vice-versa. Although there is no rule stipulating that uninominal candidates must have experience as a leader of a grassroots organization, this is almost always the case. As a former deputy commented, "it is practically impossible to become a uninominal candidate for MAS if you do not have experience as a [social organization] leader." ${ }^{, 52}$ Interviews with multiple uninominal representatives in La Paz, Cochabamba, Oruro, and Santa Cruz, confirm this observation. Analyses based on the 
survey of Latin American parliamentary elites conducted by the University of Salamanca show that most of them, indeed, came from a grassroots organization. ${ }^{53}$

The key actors are grassroots organizations with a territorial base. These gained legal status as Territorial Grassroots Organizations (OTBs) with the 1994 Law of Popular Participation, and they generally include neighborhood associations, traditional indigenous organizations (the ayllus), and modern peasant unions (the sindicatos campesinos). Candidate selection within MAS ensures the representation of the OTBs that decide to join the party. ${ }^{54}$

Below I examine subnational variation in the nomination of uninominal candidates according to the four party-civil society constellations outlined above.

\section{Strong Civil Society Aligned with MAS}

Where civil society is strongly organized and aligned with MAS, as in the western departments of La Paz, Cochabamba, Oruro, and Potosí, decentralized participation tends to be the norm. The process begins at the lowest organizational level of the union structure, the sindicatos campesinos, and then moves up to the territory's higher organizational levels, the subcentrales and the centrales. ${ }^{55}$ In general, the subcentral aligns with the territory of the electoral district, meaning that there is generally one subcentral per electoral district. The following account portrays an "ideal typical" model through which MAS selects uninominal candidates.

The selectorate for such candidacies is highly inclusive, and there is a clear emphasis on extending grassroots participation. As Vice President Álvaro García Linera commented in an interview, because "these candidates are not handpicked, they are not the candidates of the party 
in a strict sense. They are selected by grassroots organizations as a function of their territorial power, and they are the representatives of those organizations."

Selection can be summarized in three steps. First, each sindicato and other OTBs in a given district organize meetings to conduct a preliminary screening of potential candidates and then select their nominees. These meetings, called ampliados or cabildos, are crowded events that ensure broad grassroots participation. The individuals who are elected at this level then represent their organization at the next highest level of organization, the subcentrales. At this level, each subcentral holds an ampliado or a cabildo to choose among the sindicato-level nominees. The winner of each subcentral contest then goes on to compete for representation at the next highest level of organization, the central. The candidates for each electoral district are defined at this level, as seen below.

Finally, the central organizes an ampliado or a cabildo with all of the nominees presented by the subcentrales. The winners at this level typically emerge as uninominal candidates if they receive the support of all the organizations involved throughout the process. The runners-up serve as substitute candidates for the district.

\section{Strong Civil Society Aligned with Opposition}

The expansion to the east, where MAS was historically weak, pushed decision-making structures into a more oligarchic direction. ${ }^{57}$ In parts of Santa Cruz, particularly in rural districts, the selection of uninominal candidates followed the familiar "bottom up" pattern described above; in contrast, in the city of Santa Cruz, where there are strong organizations aligned with opposition forces, a local party structure played an influential role and nominated several candidates from its ranks. ${ }^{58}$ However, department level selection also involved alliance and 
coalition building with other parties, with politically influential groups and non-traditional organizations, and with a wide array of ad hoc urban organizations. Such alliances guaranteed representation for members of those groups, and were made by the national leadership; neither the local party, nor the grassroots organizations that control the Regional Directorate, created them. ${ }^{59}$ The composition of the electoral list reflected an internal balance of power that favored those urban groups over peasant organizations, reflecting a more centralized and exclusive selection pattern that strengthened the influence of a small party elite. ${ }^{60}$ It also revealed a strong pragmatism by the top party leadership. Evidence from other eastern departments, where major civil society organizations are aligned with the opposition, reveals a similar pattern of candidate selection that combines participation from below with oligarchic decision-making.

\section{Strong Civil Society with Multiple Alignments}

The fact that MAS has grown fast and in a decentralized manner has allowed newly incorporated local organizations significant influence on candidate selection. Generally, their decision to be a part of MAS implies mutual benefits. MAS opens its electoral lists and gives these organizations control over the selection process. Thus, MAS benefits from the social networks and organizational infrastructure of these organizations, which are able to organize campaigns and mobilize resources more efficiently. In turn, grassroots organizations benefit from the association with MAS, which generally increases their likelihood of electoral success.

This symbiotic relationship is different in rural and urban environments, however. Grassroots organizations with a territorial base are central to selection in both settings, but in urban areas there are usually no clearly identifiable organizations that exert dominance over the territory. Rather, there is a multiplicity of neighborhood associations, professional associations, 
cooperatives, unions and the like. Since they usually are in competition during the selection process, these competing organizations often have difficulty agreeing on a preferred candidate. When conflicts arise and competing organizations cannot reach agreement, a small party elite that often includes the president himself acts as an arbiter and has the last word. As I describe further below, the failures of coordination among grassroots actors create an organizational space for the leadership to centralize power, pushing internal decision-making structures into a more oligarchic direction.

\section{Weak Civil Society}

In rural areas, particularly where grassroots organizations have dominant control over the territory, MAS has not invested much in the building of a party branch independent of these

organizations. ${ }^{61}$ In urban areas, by contrast, and particularly in places where grassroots organizations are not strong, or where they do not have dominant control over the territory, MAS has constructed territorial party organizations of varying strength. For the most part, however, these structures lack independent decision-making power, creating an organizational opportunity for the party leadership to centralize power in contexts where civil society is weak.

\section{Summary}

Systematic evidence from the departments of La Paz, Cochabamba, Oruro, and Santa Cruz, complemented by observations of other departments, suggests that the crucial variable determining the nature of candidate selection is the strength of civil society - both number of members and the ability of grassroots organizations to reach an agreement on selection. In this scenario, MAS diffuses power among territorially grounded grassroots actors, which generally 
have the last word on selection. Once these organizations nominate a candidate, this person becomes a candidate for MAS. However, when conflicts emerge among competing organizations, MAS tends to concentrate decision-making power in the hands of a small party elite - and even Morales himself. These disputes are rarely resolved through formal channels, or by the local party organization. These dynamics are more commonly observed in urban areas, where the political space is more fragmented, and in the eastern departments, where MAS expanded by means of a "catch-all" strategy of recruitment.

\section{PLURINONMINAL CANDIDATES}

Districts for plurinominal candidates are larger, meaning that there are different partycivil society constellations within each district. It also means that coordination among competing organizations is generally more complicated than in uninominal districts. Conflicts among such organizations create an organizational opportunity for the party leadership to centralize power.

Indeed, plurinominal candidates and candidate list placement typically emerge from agreements between the leadership of MAS and specific social sectors, or are directly selected by Morales. These candidacies help to generate balances - territorial, corporate, urban/rural, and male/female - after the list of uninominal candidates is approved. ${ }^{62}$ In this instance the selection process is more centralized; the principal actors are either national party leaders, members of the national-level government, or brokers with access to patronage resources in departmental governments, and ultimately Evo Morales himself.

Although the selection of plurinominal candidates is more centralized and exclusive, and therefore more oligarchic, it serves as a part of a deliberate strategy of addition that allows for the incorporation of sectors and groups that do not have a territorial or an institutional corporate 
base. As Leonida Zurita commented, "the idea is to include everyone - that is, professionals, non-professionals, intellectuals, non-intellectuals, indigenous and nonindigenous middle class, women, and so on. It is in that sense that our project is one of inclusion and not of exclusion." This view is akin to the view of Concepción Ortiz, MAS's Vice President, who stated that this mechanism allows MAS to balance its electoral lists, and is seen by the leadership as an inclusionary way to give representation to urban middle classes. ${ }^{63}$

Formal membership and a background as a movement leader are not conditions for candidacy. As a result, rural and peasant organizations generally view plurinominal candidates without such a background as unwelcome competitors. They consider themselves the authentic representatives of MAS. Indeed, plurinominal candidates are often referred to as "invited." That characterization is used to contrast "organic" rural-based rank and file with "invited" urban and middle classes.

This form of nomination was not widespread during the early days of MAS. Rather, as Do Alto and Stefanoni suggest, the invitation of candidates only became common during the 2002 election, when MAS became a national-level actor. ${ }^{64}$ MAS developed an expansive strategy of electoral recruitment and coalition building in order to compete successfully for the presidency and congress. The idea behind this strategic maneuver was initially simple: to recruit indigenous and nonindigenous middle classes, left-leaning and nationalist intellectuals, social movement leaders, and professionals, among others, in order to expand the electoral base.

The strategy of invitation has changed over time, however, and it has served as a mechanism of accommodation that gives MAS flexibility in changing electoral and political environments. It has also been useful once the party assumed power. According to Bolivian journalist Fernando Molina, once MAS gained power, the growing presence of "invited" 
candidates has responded to two factors: "first, the need to improve the efficiency of the new regime, and second, the co-optation of the 'process of change' by bureaucratic and intellectual classes. ${ }^{" 65}$ Molina's account assumes that MAS of necessity has adapted to, and has been absorbed by, the state apparatus, and that "invited" candidates are just a reflection of those dynamics. However, while there are oligarchic tendencies within the legislative group, and while these have intensified after MAS assumed power, Molina's conclusion can be misleading. It is possible that "invited" MAS candidates and social movement representatives do not form any sort of organic group with shared or corporate social and political interests and incentives - that is, they do not form an oligarchy. At best, they represent a temporary group of assorted representatives from diverse base organizations in a loose coalition.

Molina's functionalism also downplays the choices and power struggles within the party and the diverse selection mechanisms used by MAS. According to Jorge Silva, the leading campaign advisor for the 2009 election, it is important to make an analytic distinction between plurinominal candidates invited directly by Morales, and those candidates nominated by social organizations. Most of the former are invited because they are considered "symbolic figures or political emblems that can give certain vitality to the government. In these cases, the selection decision does not come out from the social organizations but rather from the top down. ${ }^{, 66}$ In other words, the source of legitimacy for these candidates comes from their accumulated symbolic capital. The rationale behind these nominations is to capture the median voter. ${ }^{67}$

The analysis provided thus far characterizes the selectorate as highly exclusive. It is therefore possible to argue that the nomination process of plurinominal candidates within MAS resembles an "appointment system," but that would be an oversimplification. ${ }^{68}$ 
My research shows that many plurinominal candidates are nominated by a wide array of social movements, unions, and civic associations that, among other base organizations, compete for representation. As in the case of the uninominal candidates, prior to an election cycle MAS's National Directorate distributes an open call for nominations to sponsoring and allied organizations throughout the country. After the invitation is out, the social organizations allied to MAS - or those that intend to join and nominate candidates - propose their preferred candidates. According to Jorge Silva, since these nominees are "neither members nor activists of the social organization nor formal members of MAS, it is only in this sense that we can say they are invited. It is not the president who brings them or imposes them on the organizations, but rather the organizations actually make the invitations." ${ }^{, 69}$

In these cases, then, the power struggles among competing organizations to nominate their own candidates, and the way in which conflicts emerging from these struggles are resolved, are central to selection. To increase the likelihood of nominating their preferred candidates, competing organizations need to coordinate with other groups. Coordination is not always easy, however.

An example of the selection of senatorial candidates from the Department of Cochabamba will illustrate how the selection of plurinominal candidates works. Of the list of four senators, the first slot went to Adolfo Mendoza, who had served as a legal and political advisor to peasant organizations during the constituent assembly; the second slot went to Marcelina Chávez, who is both a miner in a cooperative and a peasant union leader; the third slot went to Julio Salazar, who was a prominent coca-growing union-leader in the Six Federations of the Tropic of Cochabamba in the Chapare region; and the fourth slot went to Lidia Ordónez, who was loosely associated to the "middle" class. ${ }^{70}$ 
Mendoza explains why he obtained the first slot:

[W]e knew that we were going to win at least two seats, but not the four seats in the Department. The Six Federations of the Tropic of Cochabamba wanted the first seat for themselves, but that would have been a risky move, electorally speaking. [...] Since the Bartolinas and the Six Federations did not come to an

agreement $[\ldots]$, they decided to invite me because they knew me by my work in the constituent assembly. I was also a visible person nation-wide, as I had led a public campaign to defend the constitution in Cochabamba before it was approved, and as a result they thought that my candidacy would secure urban middle-class votes and increase the probabilities of winning, if not four seats, at least the first three. I was someone associated with the construction of the Plurinational State, but people knew I wasn't in MAS. In fact, I didn't become a candidate because I was a member of MAS, or even a leader of a social organization, but thanks to my collaboration with these. And it wasn't Morales who invited me, but rather these organizations. ${ }^{71}$

\section{Failures of Coordination}

Even in the case of uninominal candidates, competing social organizations often do not reach a consensus in the selection process, failing to nominate candidates. To date, there are neither clear hierarchies nor clearly established formal structures and mechanisms to resolve these conflicts within MAS. The Regional Directorates, as intermediate-level party bodies, may play an important role in this regard. However, just like the local party apparatus, they do not have sufficient autonomy and decision-making power, and they try "not to obstruct the decisions 
made by the executive or by the social organizations themselves." ${ }^{, 72}$ In the absence of clear mechanisms for conflict resolution, most participants end up relying on Morales to decide. He plays the role of arbiter in chief, particularly in areas where the political apparatus is weaker (e.g., in Beni, Pando, and Tarija). In cases where MAS has developed a stronger party apparatus (e.g., in Cochabamba, La Paz, and Santa Cruz), conflicts are resolved by the intervention of local powerful political actors who exert significant influence on intraparty decisions, but also by Morales himself.

When it comes to plurinominal candidates, ad hoc committees composed by a small group of influential leaders are often formed to decide the final composition of the electoral lists. While this is an ad hoc arrangement, interviews with plurinominal candidates suggest that this group typically includes the President, the Vice President, the Presidents of Congress, leaders of MAS's National Directorate, and leaders from the MAS's core organizations. Additional leaders sometimes are included. These groups evaluate the lists proposed by social organizations in each department, and then negotiate with these organizations to determine which individuals will be selected.

These groups can also veto candidates already proposed. Their ability to do so, however, is contingent on structural elements. Two examples with differences in structural context may help illustrate this point. The first is in Santa Cruz, where civil society is strong and aligned with opposition forces. In such a context, vetoes from the top succeeded when regional organizations engaged in an alliance with the Unión Juvenil Cruceñista (UJC), a right-wing shock troop that had violent confrontations with MAS activists during the first Morales government. This alliance would guarantee the UJC an important number of seats, which the leadership did not accept. In other cases, however, despite the veto attempts by committees, social organizations manage to 
nominate their preferred candidate. Generally, this occurs where strong grassroots organizations are aligned with MAS, as in the Department of Cochabamba.

\section{Summary}

The selection of plurinominal candidates is more centralized and exclusive than that of uninominal candidates. The process can be characterized as a combination of top-down decisionmaking by a small - but varying - group of influential leaders, and negotiation and consensus building from below. While in some cases the leadership can exert significant influence on the order and composition of the lists, in other instances the social organizations have more power to nominate their preferred candidate. Consistent with the main argument here, this is generally the case in areas where social organizations are stronger and aligned with MAS. When this is not the case, the leadership has more control over candidate selection.

\section{CONCLUSION}

The rising popularity and ascent to power of movement-based parties (MBPs) is a rapidly spreading phenomenon. This development calls for a new theoretical understanding of their internal politics, one that helps us move beyond the caricature of an inevitable "iron law" toward a more nuanced understanding of new and, arguably, more participatory forms of organization. Using original empirical evidence on how the Bolivian MAS selects candidates, I have explained the conditions and mechanisms under which broad and substantive grassroots participation can be promoted in contemporary governing parties formed by social movements. Where civil society is strong, has mechanisms to arrive at collective decisions, and can reach agreements on candidate selection, it can play an important role in defying the oligarchization of allied MBPs 
by maintaining open political spaces for democratic participation from below. This is particularly the case for uninominal candidates. Thus, electoral rules create the space for social movements to shape the process.

This analysis has implications for understanding internal sources of party variance. Just as parties deploy multiple strategies to attract different electoral constituencies, they also operate differently in different settings depending on how the political space is structured. I have shown that variation in patterns of party-civil society relations shape the internal life of parties. The evidence and analysis suggest that internal party processes should not be seen as a mere reflection of formal institutional rules governing a country. While these are important and are manifested, for example, in electoral rules, they do not fully explain sources of variation within MBPs, nor between them. ${ }^{73}$ To understand how parties operate, then, it is crucial to examine the organizational context in which they are embedded, and how this varies geographically.

What significance does this argument have for Latin American politics? The era of party building in the region is far from over. Over the last two decades, new parties representing the interests of those historically marginalized have emerged and risen to power in the region. Some of these parties combine charismatic leadership with a grassroots movement base, like MAS, the Brazilian PT, and the Uruguayan FA. A central goal for these parties in power has been to construct more participatory modes of democratic governance. However, sustaining participation is challenging when governing at the national level. While some leaders in power have transformed their parties into personalistic vehicles, as in the cases of Venezuela and Ecuador, the analysis presented in this article reveals a different, and arguably more promising, bottom-up pattern of participation. At least in the realm of candidate selection, organized popular constituencies can, under certain conditions, limit the power and autonomy of the party 
leadership, and exert decision-making power. Their influence over selection outcomes has been consequential in Bolivia's political process: it has led to large-scale participation by individuals and previously under-represented groups at the highest level of representation in the country; ${ }^{74}$ their participation in Congress has contributed to diversifying the legislative agenda, making their interests increasingly harder to be ignored. ${ }^{75}$

Thus, in addition to conceiving of MBPs simply as electoral vehicles, we should theorize about them as promising instruments for the successful incorporation into politics of historically marginalized popular groups. This conclusion speaks to the potential consequences of social movements at the structural level, marking the achievement of lasting influence and shaping options for excluded groups to gain representation in organized politics. To understand new patterns of representation and incorporation in young democracies, which are occurring through more fluid structures than in the past, we need more research on the internal life of MBPs. 


\section{NOTES}

I thank Evelyne Huber for her insights and advice while preparing this article. For feedback on earlier versions, I thank Anne DeCecco, Russell Bither-Terry, Juan Bogliaccini, Jennifer Cyr, Tulia Falleti, Eric Hershberg, Herbert Kitschelt, Juan Pablo Luna, Sara Niedzwiecki, Judy Rein, Graeme Robertson, Lars Schoultz, John D. Stephens, and Milada Vachudova. The fieldwork cited in this article was supported by the Graduate School at UNC-Chapel Hill and a Mellon Dissertation Fellowship granted by the Institute for the Study of the Americas, at UNC. I acknowledge the support of the Center for Latin American and Latino Studies at American University and Tulane University's Center for Inter-American Policy \& Research. Finally, I thank three anonymous reviewers, who offered invaluable feedback.

${ }^{1}$ Joachim Jachnow, "What's Become of the German Greens?" New Left Review 81 (May-June, 2013), 95-117.

${ }^{2}$ Steven Levitsky, James Loxton, and Brandon Van Dyck, "Introduction: Challenges of Party-Building in Latin America," In Party-Building in Latin America, Ed. Steven Levitsky, James Loxton, Brandon Van Dyck, and Jorge Domínguez, n.d.

${ }^{3}$ Steven Levitsky, and Kenneth M. Roberts, The Resurgence of the Latin American Left (Baltimore: The Johns Hopkins University Press, 2011).

${ }^{4}$ Donna Lee Van Cott, From Movements to Parties in Latin America (Cambridge University Press, 2005), 39.

${ }^{5}$ Adrienne LeBas, From Protest to Parties (Oxford: Oxford University Press, 2011); Sara Roy, Hamas and Civil Society in Gaza (Princeton: Princeton University Press, 2013); Peter Mair, Ruling the Void (London: Verso, 2013); John K. Glenn, "Parties out of Movements: Party Emergence in Postcommunist Eastern Europe," In States, Parties, and Social Movements, Ed. Jack A. Goldstone, 147-69 (New York: Cambridge University Press, 2003); Mildred A. Schwartz, Party Movements in the United States And Canada (Rowman \& Littlefield, 2006).

${ }^{6}$ Herbert Kitschelt, The Logics of Party Formation (Ithaca, NY: Cornell University Press, 1989); Margaret E. Keck, The Workers' Party and Democratization in Brazil (New Haven: Yale University Press, 1992); Van Cott.

${ }^{7}$ Kenneth M. Roberts, Deepening Democracy? (Stanford, CA: Stanford University Press, 1998), 3.

${ }^{8}$ See, for example, Steven Levitsky and Kenneth M. Roberts, "Introduction: Latin America's 'Left Turn': A Framework for Analysis," In Levitsky and Roberts, 13; also, Jennifer Pribble, Welfare and Party Politics in Latin America (New York: Cambridge University Press, 2013).

${ }^{9}$ Robert Michels, Political Parties (London: The Free Press [1911], 1962). I distinguish between a "short" and a "long" version of Michels's oligarchy theory. While the former is about the centralization of authority and the progressive decrease of opportunities for participation in decision-making by the grassroots, the latter is about the growing difference between the preferences of the office-seeking leadership and those of the rank and file, and about a prevalence of decisions made in favor of the self-regarding political interests of the leaders. Juan Linz, "Robert Michels and His Contribution to Political Sociology in Historical and Comparative Perspective." In Robert Michels, Political Sociology, and the Future of Democracy, Ed. Juan J. Linz, 1-80 (New Brunswick: Transaction Publishers, 2006).

${ }^{10}$ See Maurice Duverger, Political Parties, Their Organization and Activity in the Modern State (London, Methuen, 1954); Robert McKenzie, British Political Parties (New York: St. Martin's Press, 1955); Otto Kirchheimer, "The Transformation of the Western European Party Systems," In Political Parties and Political Development, Ed. Joseph LaPalombara and Myron Weiner, 177-200 (Princeton, NJ: Princeton University Press, 1966); Richard S. Katz, and Peter Mair, "Changing Models of Party Organization and Party Democracy The Emergence of the Cartel Party," Party Politics 1 (1995), 5-28; Angelo Panebianco, Political Parties: Organization and Power (New York: Cambridge University Press, 1988).

${ }^{11}$ Reuven Y. Hazan, and Gideon Rahat, Democracy within Parties (Oxford: Oxford University Press, 2010); William Cross, and Richard S. Katz. The Challenges of Intra-Party Democracy (Oxford: Oxford University Press, 2013).

${ }^{12}$ See Pribble, Jennifer; also, Huber, Evelyne, and John D. Stephens. Democracy and the Left (Chicago: University of Chicago Press, 2012).

${ }^{13}$ Steven Levitsky, "Inside the Black Box: Recent Studies of Latin American Party Organizations," Studies in Comparative International Development 36, 2 (Summer, 2001): 92-110; also, Stephanie L. Mudge, and Anthony S. Chen, "Political Parties and the Sociological Imagination: Past, Present, and Future Directions," Annual Review of Sociology 40 (July, 2014), 320. 
${ }^{14}$ On the first point, see Jennifer Cyr, "From Collapse to Comeback? The Fates of Political Parties in Latin America," Ph.D Dissertation (Northwestern University, 2012); on the second point, see Levitsky, Loxton, and Van Dyck.

${ }^{15}$ Recent examples include Brandon Van Dyck, "The Paradox of Adversity: New Left Party Survival and Collapse in Latin America," Ph.D Dissertation (Harvard University, 2013); also Margit Tavits, Post-Communist Democracies and Party Organization (New York: Cambridge University Press, 2013).

${ }^{16}$ Thus, in parallel to workplace democracy, party democracy can promote the involvement of groups and individuals in decision-making by promoting participation, and by extending substantive decision-making authority. See Carole Pateman, Participation and Democratic Theory (Cambridge University Press, 1970).

${ }^{17}$ Therefore, the goal is neither to refute Michels's "iron law" nor to prove that it simply does not apply everywhere. My approach is thus akin to the one followed by Lipset, Trow, and Coleman in their study of the conditions affecting union democracy, whose goal was to explain the mechanisms that might enable or hinder the maintenance of democracy in organizations. See Seymour Lipset, James S. Coleman, and Martin A. Trow, Union Democracy (New York: Free Press [1956], 1977), 13.

${ }^{18}$ See E. E. Schattschneider, Party Government (New York: Farrar and Rinehart, 1942), 64; see, also, Michels, 182; Duverger, 151; and Kirchheimer, 198.

${ }^{19}$ The study of candidate selection for the executive branch requires separate treatment since presidential races are more personalistic enterprises; they tend to strengthen the importance of strong personalities and thus contribute to undermine the role of candidate selection procedures in relation to individual groups.

${ }^{20}$ The MAS has adopted agenda items, priorities, and actions at the behest of its strongest allied grassroots organizations that wield power on candidate selection. This is evident, for example, in the development of agrarian and mining policies. It has also reversed policy decisions when confronted by mobilizations of those allied groups. See Santiago Anria, "Social Movements, Parties, and the Left in Latin America," Ph.D Dissertation (University of North Carolina at Chapel Hill, 2015).

${ }^{21}$ Although the German Social Democratic Party, the subject of Michels's analysis, had been around for decades when Michels formulated his theory, the party lacked experience exercising national power. What is striking about MAS is that it has so far resisted the effects of oligarchization even after assuming national power. MAS was founded in 1995, it became a national-level actor in the 2002 election, and finally won the presidency in 2005 , only ten years after its emergence, being reelected in 2009. The young age at which it first came to power and the lack of extensive experience exercising subnational power set the case apart, particularly when compared to contemporary cases like the Brazilian PT and the Uruguayan FA. See Anria 2015.

${ }^{22}$ Wendy Hunter, The Transformation of the Workers' Party in Brazil, 1989-2009 (New York: Cambridge University Press, 2010); Pedro Ribeiro, "An Amphibian Party? Organisational Change and Adaptation in the Brazilian Workers' Party, 1980-2012," Journal of Latin American Studies 46, 1 (February, 2014), 87-119.

${ }^{23}$ Wendy Hunter, "The Normalization of an Anomaly: The Workers' Party in Brazil," World Politics 59, 3 (April, 2007), 440-75.

${ }^{24}$ Critics may argue that, given the young age of MAS, it might be "too early to tell" whether the process of oligarchization has had time to fully develop. I am not claiming that MAS will remain open to grassroots input in the future and defy oligarchy in the long run. It is likely that MAS will become increasingly oligarchical if it becomes a hegemonic power holder, like South Africa's ANC, but it is also theoretically plausible that if it loses power it will seek to revitalize linkages with the grassroots. There is no good reason to assume a priori that parties like MAS will develop in a uniform manner. I am theorizing about the necessary conditions for the maintenance of democratic patterns within such parties.

${ }^{25}$ For a recent review of this literature, see Mudge and Chen, 310-212.

${ }^{26}$ See Panebianco; Herbert Kitschelt, The Transformation of European Social Democracy (Cambridge University Press, 1994); Edward L. Gibson, "The Populist Road to Market Reform: Policy and Electoral Coalitions in Mexico and Argentina," World Politics 49, 3 (1997), 339-70; Steven Levitsky, Transforming Labor-Based Parties in Latin America (Cambridge: Cambridge University Press, 2003).

${ }^{27}$ Kitschelt, Herbert. "Linkages between Citizens and Politicians in Democratic Polities," Comparative Political Studies 33, 6-7 (August/September, 2000), 845-79; Juan Pablo Luna, Segmented Representation (Oxford: Oxford University Press, 2014).

${ }^{28}$ For a general review, see Bonnie N. Field, and Peter M. Siavelis, "Candidate Selection Procedures in Transitional Polities A Research Note," Party Politics 14, 5 (September, 2008), 620-39. On Latin American parties, see Kathleen Bruhn, "Electing Extremists? Party Primaries and Legislative Candidates in Mexico," Comparative 
Politics 45, 4 (July, 2013), 398-417; Gilles Serra, "Why Primaries? The Party's Tradeoff between Policy and Valence," Journal of Theoretical Politics 23, 1 (2011), 21-51.

${ }^{29}$ Levitsky, 2003, p. 4. The term "core constituency" comes from Gibson, 1996; it refers to sectors of society that provide financial resources, policymaking support, guidance, and mobilizational power to an allied movementbased party.

${ }^{30}$ Herbert Kitschelt, "Movement Parties," In Handbook of Party Politics, Ed. Richard S. Katz and William Crotty, (Sage Publishers, 2006), 283.

${ }^{31}$ Roberts, 1998 , p. 75.

${ }^{32}$ Kitschelt, 2006, 285-288.

${ }^{33}$ Ibid, p. 288.

${ }^{34}$ Peter M. Siavelis, and Scott Morgenstern, "Candidate Recruitment and Selection in Latin America: A Framework for Analysis," Latin American Politics and Society 50, 4 (December, 2008), 37-38.

${ }^{35}$ John M. Carey, and Matthew S. Shugart, "Incentives to Cultivate a Personal Vote: A Rank Ordering of Electoral Formulas," Electoral Studies 14, 4 (December, 1995), 417-39.

${ }^{36}$ Brandon Van Dyck, "Why Party Organization Still Matters: The Workers' Party in Northeastern Brazil," Latin American Politics and Society 56, 2 (April, 2014), 1-26; Tavits, 2013; LeBas, 2011; Levitsky, 2003.

${ }^{37}$ See Van Cott; Levitsky, Loxton, and Van Dyck; and Alberto Vergara, "United by Discord, Divided by Consensus: National and Sub-National Articulation in Bolivia and Peru, 2000-2010," Journal of Politics in Latin America 3, 3 (December, 2011): 65-93. On Africa, see LeBas, 2011. On Europe, see Kitschelt, 1989.

${ }^{38}$ This pressure may also defy oligarchy by helping to keep channels open for agenda setting from below, and can thus contribute to keeping parties responsive to societal demands. See Anria 2015.

${ }^{39}$ The term "political alignments"- or to be "politically aligned"-refers to a shared understanding that both civil society organizations and the party belong to the same political camp (in other words, it is not about formal organizational ties).

${ }^{40}$ Sarah A. Soule, "Bringing Organizational Studies Back in to Social Movement Scholarship," In The Future of Social Movement Research, Ed. Jacquelien van Stekelenburg, Conny Roggeband and Bert Klandermans, 107-23 (Minneapolis: University of Minnesota Press, 2012).

${ }^{41}$ Graeme B. Robertson, The Politics of Protest in Hybrid Regimes (Cambridge: Cambridge University Press, 2010).

${ }^{42}$ Luna, 2014.

${ }^{43}$ On its emergence, see Van Cott; Madrid, Raúl, The Rise of Ethnic Politics in Latin America (Cambridge: Cambridge University Press, 2012); and Anria, Santiago "Social Movements, Party Organization, and Populism: Insights from the Bolivian MAS," Latin American Politics and Society, 55, 3 (2013), 19-46.

${ }^{44}$ MAS statutes do not stipulate a unified candidate selection method. Article 37 says that grassroots organizations aligned with the party should select candidates through whichever "democratic" means they consider appropriate. Thus, statutes recognize a variety of selection mechanisms.

${ }^{45}$ Moira Zuazo, ¿Cómo Nació El MAS? (La Paz: Fundación Ebert, 2008); Sven Harten, The Rise of Evo Morales and the MAS (London: Zed Books, 2011); Hervé Do Alto, and Pablo Stefanoni, "El MAS: Las Ambivalencias de La Democracia Corporativa," In Mutaciones En El Campo Político Boliviano, 305-63 (La Paz: UNDP, 2010).

${ }^{46}$ While these departments do not cover the entire country, the patterns observed there were also common elsewhere, as confirmed through interviews with representatives and social movement leaders from other departments in the country.

${ }^{47}$ Additional evidence from candidate selection for local level office in five municipalities - three urban (La Paz, El Alto, and Santa Cruz) and two rural (Achacachi and Villa Tunari) - provides supplementary support to the claims developed here. I find that, at the local level, the candidate selection patterns that most clearly diffuse power can be observed in municipalities where strong grassroots organizations control the territory, something that happens more frequently, though not exclusively, in rural districts. Where civil society is strong, has mechanisms to arrive at decisions, and can reach agreements on candidate selection - as in the cases of Villa Tunari and El Alto - it can play an important role in defying the trend toward oligarchization of an allied MBP.

${ }^{48}$ The demographic and economic structures of Bolivia's eastern and western departments are notoriously different. Led by the economically powerful Santa Cruz, the economy in the East is dominated by large agribusiness and natural gas production. While the image of the East as "white and wealthy" is far from true, those departments remain the country's economic engine; and though there are sizable indigenous groups, as well as rural and urbanpopular organizations, they remain far less organized than in the western departments. Civil society density is lower 
in the East. For this reason, the "bottom-up" strategy of organizational growth and electoral recruitment used by the MAS in the western departments could not be easily replicated in the eastern ones. Moreover, conflicts over natural resources between the East and the MAS-led government between 2006 and 2008 made it particularly difficult for the MAS to deploy a participatory strategy in those departments.

${ }^{49}$ In the 2009 general election MAS gained 26 of 36 seats in the Chamber of Senators, 33 of the 53 plurinominal representatives, 49 of the 70 uninominal representatives, and 6 of the 7 special seats.

${ }^{50}$ The case of Adolfo Mendoza, discussed below, illustrates a pattern in which grassroots organizations had different preferences in terms of candidate selection from the MAS national leadership, including Evo Morales, and ultimately won out. Initially, Mendoza was designated to run as a uninominal candidate; Morales tried to veto his candidacy, and yet the grassroots groups that had nominated Mendoza maintained him on the list of candidates. The fact that Mendoza then ran as a senator rather than as a uninominal deputy had to do with electoral considerations.

${ }^{51}$ Interview with Leonilda Zurita, Secretary of Foreign Relations, MAS National Directorate, La Paz, 6 November 2012.

${ }^{52}$ Interview with Dionicio Núñez, MAS founding member; former deputy for La Paz, 22 November 2012.

${ }^{53}$ María Teresa Zegada, and Jorge Komadina, El Espejo de La Sociedad (La Paz: CERES/Plural, 2014).

${ }^{54}$ By "joining MAS" I mean the process by which grassroots organizations align politically with MAS and engage in competitive nomination processes.

${ }^{55}$ The sindicato is the organization that brings together almost all of the families in a given community. Affiliation is voluntary and the requirements for affiliation include living and having land within that community. The subcentral is an intermediate structure between the sindicatos and the centrales. It is generally elected through the vote of the members of the sindicatos. The central brings together all of the subcentrales in a given province, and it is the highest level of authority in the local-level sindicato structure.

${ }^{56}$ Interview with Álvaro García Linera, Bolivia’s Vice President, La Paz, 4 May 2013.

${ }^{57}$ Jorge Silva commented that the objective for the 2009 election was "to reach an absolute majority in both chambers in the Congress at whatever cost." Thus, it is reasonable to expect a pragmatic approach to selection and alliance building. Interview with Jorge Silva, MAS campaign coordinator, La Paz deputy, La Paz, 25 January 2013.

${ }^{58}$ The configuration of this unusually strong party structure is a function of a deliberate decision by MAS's leadership to consolidate its presence in an area that was seen as hostile to MAS. Interview with García Linera.

${ }^{59}$ Interviews with Isaac Ávalos, MAS Senator for Santa Cruz, La Paz, 30 August 2012; Lidia Choque, former MAS-Santa Cruz President, Santa Cruz, 16 May 2013; Gabriela Montaño, MAS Senator for Santa Cruz; President of the Senate, La Paz, 28 February 2013; and José Quiroz, President, MAS-Santa Cruz, Santa Cruz, 21 May 2013.

${ }^{60}$ Lidia Choque commented that the "agreement 'from above' could have only happened because the social organizations [in Santa Cruz] are not united and each supports whoever offers the best deal."

${ }^{61}$ Evo Morales commented some time ago that, "where the grassroots organizations are strong, there is no need to organize MAS.” Interview with Leonida Zurita.

${ }^{62}$ Interviews with Adolfo Mendoza, MAS Senator for Cochabamba, La Paz, 29 November 2012; also, with Álvaro García Linera.

${ }^{63}$ Interview with Concepción Ortíz, Vice President, MAS National Directorate, Santa Cruz, 6 November 2012.

${ }^{64}$ Do Alto and Stefanoni, p. 312.

${ }^{65}$ Fernando Molina, "El MAS En El Centro de La Política Boliviana," In Mutaciones en el campo político boliviano, 279.

${ }^{66}$ Interview with Adolfo Mendoza.

${ }^{67}$ Multiple interviews.

${ }^{68}$ Hazan and Rahat, pp. 73-86.

${ }^{69}$ Interview with Jorge Silva.

${ }^{70}$ Of these four candidates, only the first three were elected in the 2009 election.

${ }^{71}$ Multiple interviews confirm the accuracy of this statement.

${ }^{72}$ Interview with Adolfo Mendoza.

${ }^{73}$ This analysis is developed elsewhere (Anria 2015).

${ }^{74}$ Vergara, p. 84.

${ }^{75}$ Zegada and Komadina. 